\title{
Valuation of Transient Evoked Otoacoustic Emissions and Distortion Product Otoacoustic Emissions in Tinnitus Patients with Normal Hearing
}

\author{
Jeong Tae Kim, Hyun Soo Lee, Hye Ran Lee, Ho Seok Choi, Byung Don Lee, and Kyurin Hwang \\ Department of Otorhinolaryngology-Head and Neck Surgery, Soonchunhyang University College of Medicine, Seoul, Korea
}

\section{정상 청력을 가진 이명 환자에서 일시유발이음향방사와 변조이음향방사의 가치}

김정태 · 이현수 · 이혜란 · 최호석 · 이병돈 · 황규린

순천향대학교 의과대학 이비인후과학교실

Received October 11, 2016

Revised November 11, 2016

Accepted November 17, 2016

Address for correspondence

Kyurin Hwang, MD

Department of Otorhinolaryngology-

Head and Neck Surgery,

Soonchunhyang University

College of Medicine

59 Daesagwan-ro, Yongsan-gu,

Seoul 04401, Korea

Tel $+82-2-709-9360$

Fax $+82-2-709-9134$

E-mail enthkr@gmail.com
Background and Objectives This study aims to verify that one of the causes of tinnitus is the malfunction of outer hair cells and, on the basis of this, to investigate the usefulness of otoacoustic emissions by performing transient evoked otoacoustic emissions (TEOAE) and distortion product otoacoustic emissions (DPOAE).

Subjects and Method Included in the study were forty-one patients who had normal hearing in the range from 0.5 to $8 \mathrm{kHz}$, and complained of unilateral tinnitus. In these patients, hearing in bilateral ears, TEOAE, DPOAE, as well as the frequency \& amplitude of their tinnitus were measured.

Results No statistically significant difference was found in bilateral hearing in patients who complained of unilateral tinnitus. However, TEOAE and DPOAE showed a statistically significant difference with their $p$-values at 0.04 and 0.004 , respectively.

Conclusion The results of this study suggested that TEOAE testing and DPOAE testing provide an important clue for verifying that the loss of outer hair cells contributed to the development of symptoms suffered by tinnitus patients with normal hearing.

Korean J Otorhinolaryngol-Head Neck Surg 2016;59(12):831-5

Key Words Hair cell · Otoacoustic emissions · Tinnitus.
서 론

사회가 발전함에 따라 전 연령에 걸쳐 이명으로 인해 고통 받는 환자의 숫자는 증가하고 있는 실태이다. 이명은 '종이 울린다’는 뜻의 라틴어인 'Tinnire'에서 유래되었으며, 외부에 서의 자극 없이 소리를 느끼는 것으로, 발생 기전에 상관없 이 신체 내부에서 나는 소리를 듣는 증상으로 정의된다.

이명을 경험해본 성인은 약 $35 \%$ 에 이른다고 알려졌으며, 지속적인 이명은 심리적, 사회적인 생활에 문제를 일으키고, 불안과 집중력 저하, 수면의 질 저하 및 우울증 등의 문제를 발생시킬 수 있는 질병이다. 또한, 이명은 난청과도 깊은 관련이
있는데, 약 85 96\%의 환자에서 청력 저하와 이명이 동시에 나 타나지만 10 15\%의 환자에게서만 정상 청력을 보인다. 아직 정상 청력을 가진 환자에서 이명의 원인은 잘 알려지지 않았 으며, ${ }^{2)}$ 최근 연구에 따르면, 이명의 중요 원인으로 와우의 기 능 이상, 그 중에서도 특히 외유모세포의 손상이 주목받고 있다. ${ }^{3)}$ 이는 이명 환자에서 이명의 원인이 외유모세포 기능 이 상이라면, 외유모세포 기능을 검사할 수 있는 이음향방사검 사를 시행하여 이를 통해 이명의 원인을 밝혀낼 수 있음을 의 미한다.

이음향방사는 와우외유모세포의 능동적 미세기계 진동 때 문에 생성되어 이소골과 고막을 거쳐 외이도에서 측정되는 것 
으로 1978년 $\mathrm{Kemp}^{4)}$ 에 의해 보고되었다. 이음향방사검사의 종류로는 일시유발이음향방사(transient evoked otoacoustic emissions, TEOAE), 주파수반응유발이음향방사(stimulus frequency otoacoustic emissions), 변조이음향방사(distortion product otoacoustic emissions, DPOAE) 등이 있다. ${ }^{5)}$

본 연구는 주관적으로 편측 이명을 호소하는 환자를 대상으 로, 외유모세포의 기능을 판단하기 위해 TEOAE와 DPOAE 를 양측 귀에서 측정하였다. 이를 통하여 정상 청력을 갖는 환 자에서 외유모세포의 기능의 변화가 있었는지를 알아보고자 한다.

\section{대상 및 방법}

\section{대 상}

2012년 1월 1일부터 2016년 5월 1일까지 본원 이비인후과 를 내원한 환자 중 양측 모두 500에서 $8000 \mathrm{~Hz}$ 범위까지 역 치가 $25 \mathrm{~dB} \mathrm{HL}$ 이내의 정상 청력을 보이며, 객관적 이명과 박 동성 이명을 보이는 환자를 제외한 주관적 이명을 호소하는 환자 중 뚜렷한 편측 이명을 호소하는 41명 환자를 대상으로 하였다. 청각적 외상, 노인성 난청, 이독성 물질 복용, 이과적 수술 및 뇌 수술의 과거력이 있거나, 전신 질환, 이과적 기형 이나 염증 등의 동반되는 귀 질환이 확인된 환자들도 제외하 였다. 총 41 명 환자의 82 귀를 대상으로 환자의 병력, 이학적 검사, 청력검사를 의무기록을 통해 후향적으로 분석하였다. 본 연구는 본원 임상연구윤리위원회의 승인 IRB(No. SCHUH 2016-05-007)를 얻은 후 진행하였다.

\section{검사 방법}

\section{순음청력검사}

한 명의 검사자가 외부와 차단되어 방음장치가 된 청력검사 실(IAC booth ${ }^{\circledR}$; IAC acoustics, Winchester, UK IL, USA)에 서 피검자를 편안히 앉힌 뒤 청력 측정기(MADSEN ORBITER 922, GN Otometrics A/S, Taastrup, Denmark)를 이용하여 청력검사를 시행하였다. 측정 전 청력 측정에 오류가 될 수 있 는 귀지나 이물은 제거하였다.

측정법으로 $250,500,1000,2000,4000,8000 \mathrm{~Hz}$ 에서 혼 합법(mixed method; 응답 후부터 자극 음의 크기를 낮출 때는 $10 \mathrm{~dB} \mathrm{HL}$, 높일 때는 $5 \mathrm{~dB} \mathrm{HL}$ 씩 조정하는 방법)을 사 용하였으며, 모든 측정치가 $25 \mathrm{~dB} \mathrm{HL}$ 이하일 경우를 정상 청 력으로 하였다. 정상측과 이명측의 비교를 위해 500,1000 , $2000,4000 \mathrm{~Hz}$ 의 주파수를 더한 후 4로 나누는 4분법을 이 용하였다.

\section{이명도 검사}

이명의 주파수(frequency)와 크기(loudness)는 동일한 일 인의 검사자에 의해 청력 측정기를 사용하여 측정하였다. 청 력검사기 안에서 나오는 $250 \mathrm{~Hz}$ 에서 $12000 \mathrm{~Hz}$ 사이에서 순음 (pure tone)에 반응이 없을 때는 협대역 소음(narrow band noise)을 협대역 소음에도 반응이 없을 때는 백색잡음(white band noise)을 사용하여 환자가 느끼는 이명의 주파수와 같 거나 비슷한 주파수를 측정하였고, 동일 주파수에서 음압을 증가시키며 환자가 느끼는 이명의 크기를 측정하였다.

\section{이음향방사검사 측정}

이음향방사의 측정은 일인의 검사자에 의해 이음향방사 분석기(Echoport ILO 292 ${ }^{\circledR}$; Otodynamics, Hatfield, UK) 를 사용하였다. 주위 소음이 $15 \mathrm{~dB}$ 이하인 무음향방음실에 서 피검사자가 안정한 각성상태에서 고감도의 마이크로폰과 두 개의 각각 다른 자극 음을 낼 수 있는 소형스피커로 이루 어진 프로브(probe)를 외이도에 적절히 밀착시킨 후 시행하 였다. 환자는 이명이 없는 쪽에서 먼저 측정하였으며, 그리고 각 측에서 $\mathrm{TEOAE}$ 를 먼저 시행 후 $\mathrm{DPOAE}$ 를 측정하였다.

TEOAE는 continuous 모드에서 최대 $80 \mathrm{~dB}$ sound pressure level(SPL)의 광대역 클릭(wide band click)을 이용하여, 1000, $1400,2000,2800,4000 \mathrm{~Hz}$ 에서 신호/잡음 비율(signal to noise ratio, $\mathrm{SN}$ ratio)을 측정하여 비교하였다.

$\mathrm{DPOAE}$ 는 DP gram으로, 두 주파수 f1과 f2에서 지속적 인 순음을 f2/f1=1.22의 비율을 유지하면서, L1, L2은 65, 55 $\mathrm{dB} \mathrm{SPL}$ 의 자극으로 자극 주파수는 $1 / 2$ octave steps로 변화 시켰으며, 1000, 1400, 2000, 2800, 4000, 6000, $8000 \mathrm{~Hz}$ 에 서 시행하였다. 측정한 $\mathrm{TEOAE}$ 와 $\mathrm{DPOAE}$ 의 신호 대 잡음비 (SN ratio)의 평균을 구하여 정상측과 이명측을 비교하였다.

\section{통계 처리}

통계는 SPSS ${ }^{\circledR}$ for window version 20.0(SPSS Inc., Chicago, IL, USA)을 이용하였으며, 평균값 데이터는 independent t-test를 실시하였고, 통계적 유의성은 $p<0.05$ 인 경우 로 하였다.

\section{결 과}

\section{환자 특성}

환자들의 평균 나이는 36.9( \pm 13.3 )세로, 10대 4명, 20대 12 명, 30대 8명, 40대 8명, 50대 9명이었으며, 우측 귀와 좌측 귀의 비율은 $22: 19$ 였다. 또한 남성과 여성의 비율은 $15: 26$ 으 로 여성이 많았다. 
순음청력검사

이명측의 청력 평균은 기도 청력 $11.16( \pm 5.6) \mathrm{dB}$, 골도 청 력 5.9( \pm 6.2$) \mathrm{dB}$ 을 보였고, 정상측의 청력 평균은 기도 청력 $10.8( \pm 4) \mathrm{dB}$, 골도 청력 5.6 $( \pm 4.3) \mathrm{dB}$ 을 보였으며, 양측의 통 계적 유의성은 없었다 $(p>0.05)$ (Table 1). 또한 정상측과 이명 측의 주파수별 평균 역시 $250 \mathrm{~Hz}$ 를 제외한 모든 부분에서 유의한 차이는 없었다(Table 2).

\section{이명의 특성}

41명의 환자 모두에서 자각적, 비박동성, 지속적 이명을 호 소하였고, 생활에 큰 영향을 미치지 않는 중등도 이명이었다. 이명도 검사를 통한 이명 주파수의 평균은 $4205( \pm 2440) \mathrm{Hz}$ 였으며, 크기는 5.84( \pm 4.37$) \mathrm{dB}$ 로 측정되었다(Table 2).

\section{일시유발이음향방사 TEOAE}

$\mathrm{TEOAE}$ 의 $\mathrm{SN}$ ratio 평균 정상측은 $11.53( \pm 3.1) \mathrm{dB}$ 을 보였 고, 이명측은 9.24( \pm 2.2$) \mathrm{dB}$ 로 이명측의 TEOAE 반응이 낮게 나타났으며, 이는 통계적으로 유의하였다( $p=0.04)$ (Fig. 1).

\section{변조이음향방사 DPOAE}

$\mathrm{DPOAE}$ 의 SN ratio 평균 정상측은 $10.8( \pm 2.1) \mathrm{dB}$ 을 보였 고, 이명측은 $3.8( \pm 1.1) \mathrm{dB}$ 로, 이명측의 DPOAE 반응이 낮 게 나타났으며, 이는 통계적으로 유의하였다( $p=0.004)$ (Fig. 2).

또한 각 주파수별로 $\mathrm{DPOAE}$ 강도(amplitude)의 평균은 정 상측이 1000, 1400, 2000, 2800, 4000, 6000, $8000 \mathrm{~Hz}$ 에서 각각 $13.2,14.5,7.5,12.2,8.9,11.3,8.1 \mathrm{~dB}$ SPL로 측정되고 이명측에서 각각 $12.2,10.1,7.2,6.7,4.8,5.1,-5.1 \mathrm{~dB} \mathrm{SPL}$ 로 측정되어 이명측이 정상측보다 전체적으로 감소한 소견을 보 였으며, $2000 \mathrm{~Hz}$ 를 제외한 주파수에서는 통계적으로 유의하

Table 1. Mean ( \pm standard deviation) of pure-tone audiometry results

\begin{tabular}{lccc}
\hline & Normal ear & Tinnitus ear & p-value \\
\hline Air conduction $(\mathrm{dB})$ & $10.8(4.0)$ & $11.16(5.6)$ & 0.829 \\
Bone conduction $(\mathrm{dB})$ & $5.6(4.3)$ & $5.9(6.2)$ & 0.615 \\
\hline
\end{tabular}

였다(Fig. 3).

\section{고 찰}

이명의 발생 기전에 대해서는 많은 이론이 있지만 아직 명확 하지 않다. 이는 한 가지 가설이나 모델이 이명에 적용되는 것 이 아니라, 이명의 발생에서는 수많은 작용기전이 존재하거나, 혹은 한 사람에서 발생한 이명은 한 가지 이상이 아닌 다양한 요소가 복합적으로 작용한다는 것을 의미한다. ${ }^{6}$

본 연구에서는 이명의 많은 원인 가설 중 하나인 와우외유

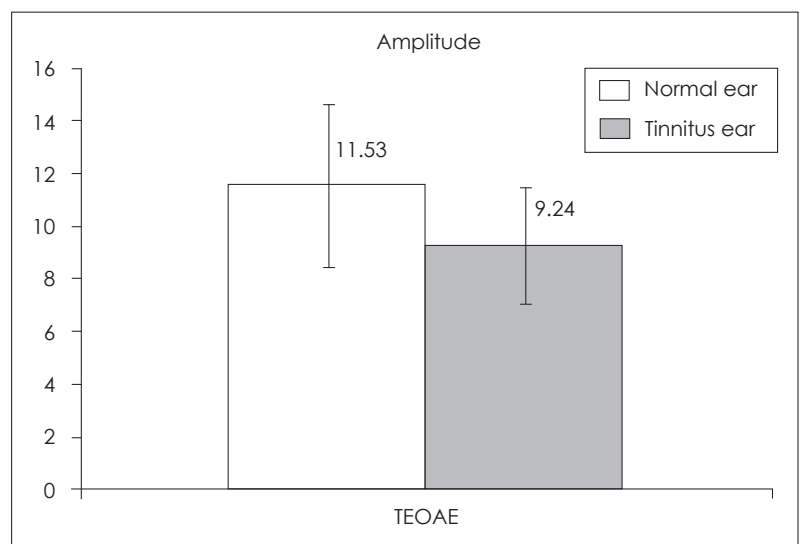

Fig. 1. Mean ( \pm standard deviation) of transient evoked otoacoustic emissions (TEOAE) in normal ear and tinnitus ear (dB).

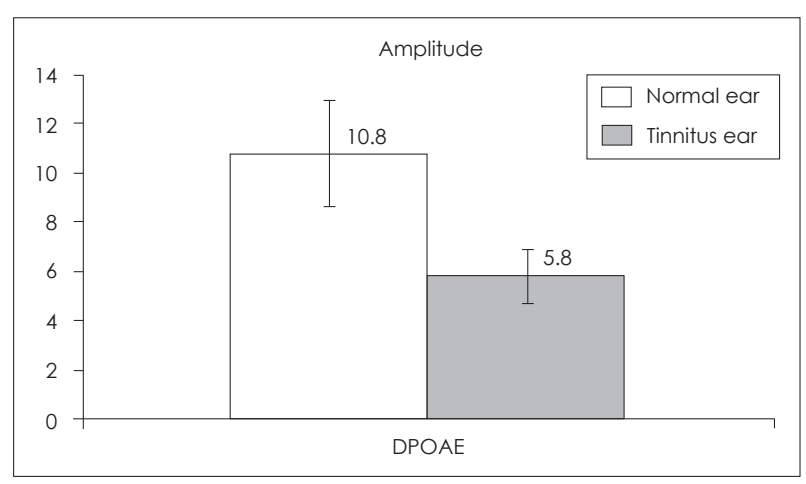

Fig. 2. Mean ( \pm standard deviation) of distortion product otoacoustic emissions (DPOAE) in normal ear and tinnitus ear (dB).

Table 2. Averaged pure-tone audiometry of tinnitus ear and normal ear, mean frequency and loudness of tinnitus

\begin{tabular}{|c|c|c|c|c|c|c|c|c|}
\hline \multirow[b]{2}{*}{$\mathrm{Hz}$} & \multicolumn{3}{|c|}{ Air conduction } & \multicolumn{3}{|c|}{ Bone conduction } & \multicolumn{2}{|c|}{ Character of tinnitus } \\
\hline & Nomal & Tinnitus & p-value & Nomal & Tinnitus & p-value & $\begin{array}{c}\text { Mean } \\
\text { frequency }(\mathrm{Hz})\end{array}$ & $\begin{array}{c}\text { Mean } \\
\text { loudness }(\mathrm{dB})\end{array}$ \\
\hline 250 & 14.41 & 15.54 & 0.782 & 3.21 & 4.18 & 0.651 & \multirow{6}{*}{$4205( \pm 2440)$} & \multirow{6}{*}{$5.84( \pm 4.37)$} \\
\hline 500 & 10.15 & 11.13 & 0.613 & 3.56 & 4.51 & 0.871 & & \\
\hline 1000 & 9.75 & 10.3 & 0.771 & 5.65 & 6.65 & 0.814 & & \\
\hline 2000 & 13.44 & 12.91 & 0.912 & 7.43 & 6.78 & 0.793 & & \\
\hline 4000 & 11.12 & 12.64 & 0.827 & 6.14 & 6.71 & 0.774 & & \\
\hline 8000 & 10.37 & 11.13 & 0.791 & 2.14 & 3.21 & 0.673 & & \\
\hline
\end{tabular}




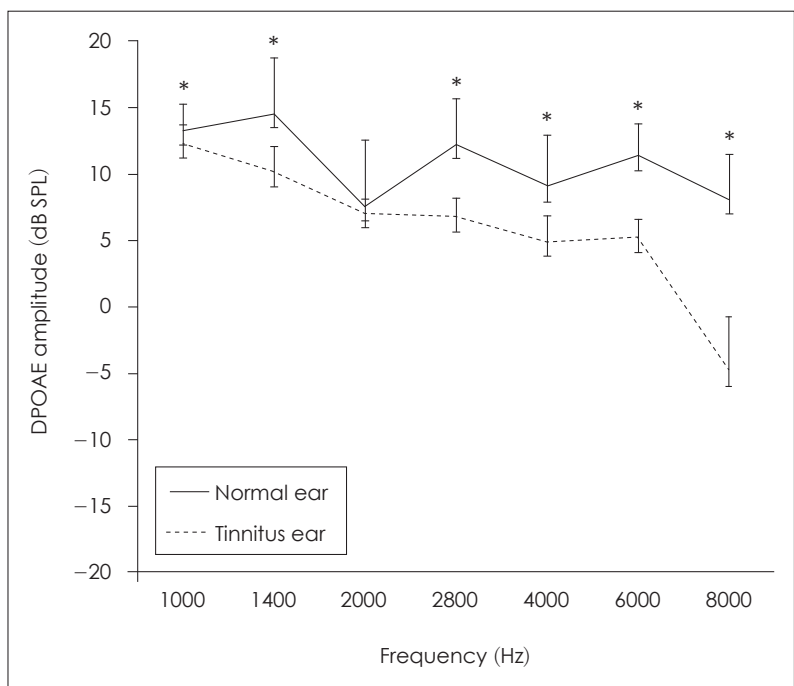

Fig. 3. Averaged DPOAE amplitudes of tinnitus ear and normal ear. *statistically significant. The averaged DPOAE amplitudes of tinnitus ear were significantly lower than normal ear except $2000 \mathrm{~Hz}$. DPOAE: distortion product otoacoustic emissions.

모세포의 영향을 파악하기 위해, 와우의 미세구조운동의 측 정방법으로 알려진 이음향방사검사를 이용하였는데, ${ }^{5)}$ 그 중 TEOAE와 DPOAE를 지표로 사용하였다. 이는 TEOAE와 $\mathrm{DPOAE}$ 가 이음향방사검사 중 가장 많이 적용되며, 여러 연 구로 가장 정확하다고 알려졌기 때문이다. ${ }^{7)}$

본 연구에서는 자발이음향방사검사(spontaneous otoacoustic emissions, SOAE)를 포함하지 않았는데, 그 이유로는 자 발이음향방사검사는 아무런 음 자극 없이 외이도에서 감지 되는 것을 말하는 것으로, 정상 청력을 갖는 환자에 있어서 $2 \%$ 에서만 정상적으로 발생하며, ${ }^{8)} \mathrm{SOAE}$ 의 주파수는 주로 1000 2000 Hz에서 생성되는 반면," ${ }^{9}$ 이명의 가장 흔한 주파 수는 $4 \mathrm{kHz}$ 이상이기 때문이다. 본 연구에서 평균 이명 주파 수는 $4205 \mathrm{~Hz}$ 로써, 만약 SOAE가 DPOAE에 영향을 미친다 고 하더라도 1000 2000 Hz 영역에 영향을 주어 본 연구에 서는 큰 영향을 미치지 않으리라고 생각하였기 때문이다.

본 연구에서 정상측과 이명측에서 TEOAE $p$-value 0.04 와 DPOAE $p$-value 0.004로 통계학적으로 유의한 결과를 얻었는데, 이는 Ceranic 등이과 Fernandes와 Santos ${ }^{11}$ 가 발 표한 정상 청력을 갖는 이명군과 이명이 없는 정상 청력을 갖 는 대조군과의 비교에서 $\mathrm{TEOAE}$ 가 이명측에서 통계학적으 로 유의하게 낮은 반응을 보인다는 결과와 일치하였으나, Geven 등리이 조사한 결과와는 일치하지 않았다. 이는 DPOAE 에 비하여 TEOAE 검사 민감도(sensitivity)가 떨어져 여러 논 문에서 다른 결과가 나온 것으로 보인다.

Sztuka 등 ${ }^{13}$ 과 Gouveris 등 ${ }^{14}$ 은 정상 청력을 갖는 이명 환자 와 이명이 없는 대조군과의 비교에서 이명 환자에서의 $\mathrm{DPOAE}$
와 정상 대조군의 $\mathrm{DPOAE}$ 가 이명측에서 통계학적으로 유의 하게 낮은 반응을 보인다는 것을 발표하여, 이명의 한 가지 원 인으로 외유모세포 손상의 가능성에 대해 발표하였는데, 이 는 본 연구 결과와 일치하였다. 또한 각 주파수에서 $2000 \mathrm{~Hz}$ 를 제외한 부분에서 이명측이 정상측에 비하여 $\mathrm{DPOAE}$ 의 강도가 유의하게 낮음을 확인할 수 있었는데, 이는 Shiomi 등 ${ }^{15)}$ 이 정상 청력을 가진 이명 환자와 난청이 있는 이명 환자 그 리고 정상 청력인을 대상으로 $\mathrm{DPOAE}$ 를 검사한 조사에서 정 상 청력인에 비해 정상 청력을 가진 이명 환자의 4000 7000 $\mathrm{Hz}$ 에서 $\mathrm{DPOAE}$ 강도가 통계학적으로 유의하게 감소한 결과 와 동일하였으며, Choi 등이이 조사한 정상 청력을 가진 이명 환자와 정상 청력인을 비교한 조사에서 정상 청력인에 비해 정 상 청력을 가진 이명 환자의 $6000,8000 \mathrm{~Hz}$ 에서 $\mathrm{DPOAE}$ 강 도가 통계학적으로 유의하게 감소한 연구를 포함한 결과다.

이번 연구에서 TEOAE와 DPOAE의 강도(amplitude)는 이명 환자에서 통계적으로 유의하게 낮은 것을 확인할 수 있 었는데, 이는 청력에 영향을 미치지는 않지만 외유모세포의 손상이 이명의 원인이 될 수 있다는 것을 의미한다. 기능이 저 하된 외유모세포는 덮개막(tectorial membrane)과 기저막 (basilar membrane) 사이의 이음(coupling)에 문제를 일으 키고 결국 내유모세포에 연결된 덮개막까지 영향을 미쳐 이 명이 발생할 수 있기 때문이다. ${ }^{16)}$ 이것은 모든 청각 경로가 이 명의 발생에 포함될 수 있지만, 이명의 발생은 주로 외유모세 포의 이상이라고 발표한 Jastreboff ${ }^{17)}$ 의 주장에 근거를 제공 한다.

위의 결과들을 종합해 볼 때 청력 이상이나 이명을 호소하 지 않는 환자에서 TEOAE나 DPOAE의 이상이 발견되었을 경우 외유모세포의 손상으로 인한 이명 발생 가능성에 대해 충분히 설명함으로써 이후 발생한 이명에 대한 환자의 인식 이나 치료에 순응도를 높일 수 있다고 본다.

본 연구에서는 한국인 집단을 대상으로 시도한 검사로, TEOAE와 DPOAE를 동시에 비교한 연구로 의미가 있다. 추후 이명의 크기와 삶의 피해 정도가 심한 이명과의 연관성 을 비교하는 추가적인 연구가 필요할 것으로 보인다.

\section{REFERENCES}

1) Heller AJ. Classification and epidemiology of tinnitus. Otolaryngol Clin North Am 2003;36(2):239-48.

2) Nicolas-Puel C, Faulconbridge RL, Guitton M, Puel JL, Mondain M, Uziel A. Characteristics of tinnitus and etiology of associated hearing loss: a study of 123 patients. Int Tinnitus J 2002;8(1):37-44.

3) Choi IS, Oh JC, Jun BH, Chang CS. Distortion product otoacoustic emission in tinnitus patients with normal hearing. Korean J Audiol 2003;7:147-51.

4) Kemp DT. Stimulated acoustic emissions from within the human auditory system. J Acoust Soc Am 1978;64(5):1386-91.

5) Woo HY, Kim YM, Kim IB, Lee JY, Jang HK, Urm SH. Test / retest 
reliability of DPOAE and TEOAE. Korean J Otolaryngol-Head Neck Surg 1998;41(12):1536-9.

6) Møller AR. Similarities between chronic pain and tinnitus. Am J Otol 1997;18(5):577-85.

7) Probst R, Hauser R. Distortion product otoacoustic emissions in normal and hearing-impaired ears. Am J Otolaryngol 1990;11(4): 236-43.

8) Kowalska S, Sułkowski W. [Tinnitus in noise-induced hearing impairment]. Med Pr 2001;52(5):305-13.

9) Cianfrone G, Mattia M. Spontaneous otoacoustic emissions from normal human ears. Preliminary report. Scand Audiol Suppl 1986; 25:121-7.

10) Ceranic BJ, Prasher DK, Raglan E, Luxon LM. Tinnitus after head injury: evidence from otoacoustic emissions. J Neurol Neurosurg Psychiatry 1998;65(4):523-9.

11) Fernandes Lda C, Santos TM. Tinnitus and normal hearing: a study on the transient otoacoustic emissions suppression. Braz J
Otorhinolaryngol 2009;75(3):414-9.

12) Geven LI, de Kleine E, Free RH, van Dijk P. Contralateral suppression of otoacoustic emissions in tinnitus patients. Otol Neurotol 2011;32 (2):315-21.

13) Sztuka A, Pospiech L, Gawron W, Dudek K. DPOAE in estimation of the function of the cochlea in tinnitus patients with normal hearing. Auris Nasus Larynx 2010;37(1):55-60.

14) Gouveris H, Maurer J, Mann W. DPOAE-grams in patients with acute tonal tinnitus. Otolaryngol Head Neck Surg 2005;132(4):550-3.

15) Shiomi Y, Tsuji J, Naito Y, Fujiki N, Yamamoto N. Characteristics of DPOAE audiogram in tinnitus patients. Hear Res 1997;108(1-2):83-8.

16) Ami M, Abdullah A, Awang MA, Liyab B, Saim L. Relation of distortion product otoacoustic emission with tinnitus. Laryngoscope 2008;118(4):712-7.

17) Jastreboff PJ. Phantom auditory perception (tinnitus): mechanisms of generation and perception. Neurosci Res 1990;8(4):221-54. 